\title{
An Exploratory Research on Entrepreneurial Ecosystems: Effects on Economic Integration
}

\author{
Assel K. JUMASSEITOVA ${ }^{1}$, Rajasekhara Mouly POTLURI ${ }^{2}$
}

Received: May 31, 2020 Revised: June 21, 2020 Accepted: July 03, 2020

\begin{abstract}
This paper investigates the influence of the economic integration exemplified by the Eurasian Economic Union on the entrepreneurial ecosystem in the Kazakhstan corporate sector. Using data collected from 204 small-, medium-, and large-sized Kazakh companies, the researchers analyzed the collected data with percentile. Findings of this study show that small- and medium-sized enterprises, especially in the tertiary sector of the Kazakh economy, are not that much affected by regional integration, whereas large firms have been significantly impacted. The originality of the paper is threefold. First, the research explores the entrepreneurial ecosystems in its focus on geographic location or digital technologies that came across mainly from the ICT space. This is becoming pervasive across mechanical systems, communications, infrastructure, and the built-up environment. Second, the originality of the paper lies in focusing on the entrepreneurial ecosystems' influence on the business processes by clearly understanding the regional, national, and international trends in different markets. Third, the paper is first of its kind to contribute an updated perspective on the entrepreneurial ecosystem's influence on economic integration to the policymakers of Kazakhstan. Policymakers will gain expertise on how to manage network effects while planning investment projects, as well as transactions, modes, and fixed nodes, acquisition, and greenfield investments.
\end{abstract}

Keywords: Entrepreneurial Ecosystem, Economic Integration, Entrepreneurship, Kazakhstan

JEL Classification Code: L25, L26, F13, F15

\section{Introduction}

Moore (1996) introduced the concept of the "business ecosystem." These days, the term has transformed into a "business ecosystem." It is generally accepted that an entrepreneurial ecosystem as an innovative construct must have four fundamental components: the idea, the entrepreneurial background of the players, funding sources, and the network that integrates these components into a comprehensive framework (Kopeikina, 2008).

${ }^{1}$ First Author and Corresponding Author. Professor, Business School, Kazakh-British Technical University, Kazakhstan [Postal Address: 59 Tole Bi Street, Almaty, A05H1T2, Kazakhstan]

Email: kense@kbtu.kz ; a.dzhumaseitova@kbtu.kz

${ }^{2}$ Associate Professor, College of Business, Al Ghurair University, United Arab Emirates. Email: rajasekhara.potluri@agu.ac.ae

(c) Copyright: The Author(s)

This is an Open Access article distributed under the terms of the Creative Commons Attribution Non-Commercial License (http://Creativecommons.org/licenses/by-nc/4.0/) which permits unrestricted noncommercial use, distribution, and reproduction in any medium, provided the original work is properly cited.
Entrepreneurial ecosystems are defined as a set of interdependent actors and factors coordinated in such a way that they enable productive entrepreneurship within a particular territory (Stam \& Spigel, 2017). The main difference with other related concepts such as Industrial District, Cluster, Innovation System, Business Ecosystems Approach is that it considers fast-growing small businesses as central players (leaders) in the creation of the system and in keeping the system healthy (Feldman, 2014), rather than larger, more established firms or slower growing SMEs. In cluster and industrial district models, high-growth start-ups are not necessarily included (Markusen, 1996).

Start-ups are explicitly placed in the center of the ecosystem. The developed financial market enhances business and economic growth by minimizing companies' external cost of borrowing. Regions with higher levels of financial improvement are, therefore, represented by higher industrial growth (Rajan \& Zingales, 1998). Entrepreneurial economy employees are not only of great importance for new value creation in developed economies like Europe (Bosma et al., 2012; Stam, 2013), but also for resourcerich developing countries due to their attempt to overcome 
middle-income trap and diversify from resource industries to the new service industries. These problems are particularly relevant for Kazakhstan, striving to build its entrepreneurial ecosystems (Jumasseitova \& Bigabatova, 2017). This research considers how economic integration with Eurasian Economic Area affects the development of an entrepreneurial ecosystem in Kazakhstan.

\section{Literature Review}

\subsection{Entrepreneurship and Entrepreneurial Ecosystems}

Entrepreneurship - or new firm formation - is a fundamental process of economic geography (Stam, 2007). While pragmatic research by economic geographers traditionally has focused on large firms as employers and as go-betweens of globalization, huge firms characteristically resume their journey as small firms and come to attention only after they become significant entities. The term entrepreneurship can be defined as the creation or extraction of value, viewed as change, which may include other values than merely economic ones (Gaddefors \& Anderson, 2017). Some narrow definitions refer to the process of designing, launching, and running a new business as a small business. The Entrepreneurship Handbook (2019) defined the term as the concept of developing and managing a business venture to gain profit by taking several risks in the corporate world, and the willingness to start a new business. Entrepreneurship is playing a vibrant role in the economic development of the developing and underdeveloped world, especially. The Business Dictionary (2019) defined the term entrepreneurship as the ability and inclination to progress, establish, and achieve a business undertaking along with any of its risks to make a profit. The most obvious example of entrepreneurship is the starting of new businesses. In economics, entrepreneurship combined with land, labor, natural resources, and capital can produce a profit. The entrepreneurial spirit is characterized by innovation and risk-taking and is an essential part of a nation's ability to succeed in an ever-changing and increasingly competitive global marketplace.

In the field of economics, Audretsch et al. (2002) defined the term entrepreneurship more comprehensively as "the entrepreneur is able to identify the marketable capacity of the creation and establish the capital, talent, and additional resources that turn an origination into a commercially-viable innovation." The famous economist Joseph Schumpeter (1883-1950) considered the entrepreneur's role in the economy as "creative destruction" - introducing innovations that concurrently abolish old industries, while steering in new businesses and methods. For Schumpeter, the changes and "dynamic uncertainty brought on by the innovating entrepreneur [were] the norm of a healthy economy." While entrepreneurship is often related to new, small, for-profit start-ups, entrepreneurial behavior can be seen in small-, medium- and large-sized firms, new and established firms, and in for-profit and not-for-profit organizations, including voluntary-sector groups, charitable organizations and government (Clifford, 2013).

Entrepreneurship may function within an, which often includes: a) government programs and services that promote entrepreneurship and support entrepreneurs and start-ups; b) non-governmental organizations such as small-business associations and organizations that offer guidance and mentoring to entrepreneurs (e.g., through entrepreneurship centers or websites); c) small-business advocacy organizations that lobby governments for augmented support for entrepreneurship programs and more small businessfriendly laws and regulations; d) entrepreneurship resources and facilities (e.g., business incubators and seed accelerators); e) entrepreneurship education and training programs presented by schools, colleges, and universities; and f) financing (e.g., bank loans, venture capital financing, angel investing and government and private foundation grants) (National Venture Capital Association, 2020). In the 2000s, the term "entrepreneurship" was widened to comprise how and why some persons (or teams) recognize opportunities, evaluate them as viable, and then decide to exploit them (Scott \& Venkatraman, 2000).

Possibly in response to the deterioration in new businesses in the current period (Decker, Haltiwanger, Jarmin, \& Miranda, 2016), entrepreneurship has not been a prominent research theme within the economic geography research in the United States (Mack \& Qian, 2016). The condition seems to have changed, as seen in the current consideration of entrepreneurial ecosystems - dynamic local social, institutional, and cultural processes and performers that inspire and improve new firm formation and growth. The typical usage of the term "ecosystem" in social science rather than an environmental context became extensive only after the effort of Moore (1993), which emphasized the business ecosystem as the company's outside milieu. Entrepreneurial ecosystems have resemblances with industrial districts, clusters, and innovation systems; entrepreneurs and spin-offs are present in these other contexts, but are not central as they are in entrepreneurial ecosystems (Stam \& Spigel, 2017). Acs, Stam, Audretsch, and O'Connor (2017) recognized that the entrepreneurial ecosystems mostly developed from literature about both business strategy and regional development. If it is a fact that "there is no such thing as an innovation system without entrepreneurs" (Hekkert, Suurs, Negro, Kuhlmann, \& Smits, 2007), then a closer emphasis on entrepreneurs is desirable. Only the entrepreneurial regional innovation system and the innovative environment visibly focus on the position of entrepreneurs (Cooke, 2007; Julien, 2007; Ylinenpää, 2009). Simultaneously, an entrepreneurial 
ecosystem also includes crucial actors in several other fields, such as large firms, universities, financial firms, and public organizations that support new and growing firms (Brown \& Mason, 2017).

The concept of an entrepreneurial ecosystem (or ecosystem for entrepreneurship) is quite new and has emerged from diverse origins, as noted above. As Stam (2015) notes, "There is not yet an extensively common description." In part, this is because ecosystems are defined in very different ways, at different scales, and with different research designs and data. Besides, there are numerous dissimilar classes of ecosystems, of which the entrepreneurial form is unique (Acs et al., 2017; Gomes, Facin, Salerno \& Ikenami, 2016). Most descriptions focus on the grouping or interface of fundamentals, often complete grids, constructing common social principles that are backing business action. Typically, an entrepreneurial ecosystem comprises numerous companies or stakeholders, as well as a set of constituents essential to the ecosystem (Erina, Shatrevich, \& Gaile-Sarkane, 2017). Amongst the most persuasive modern topographical studies are Isenberg (2011), Mason and Brown (2014), Spigel (2017a), and Stam (2015). Different conceptions have been developed and introduced by Beeche (2015), Custer (2013), Darden School of Business (2012), Nance (2013), and World Economic Forum (2013). Most of the literature and diagrams on ecosystems display all mechanisms unified; Isenberg's (2011) diagram demonstrates over fifty mechanisms under six domains. Frequently unnoticed performers are media firms, and reporters, whom Hwang and Horowitt (2012) add to the list of valuable properties in an ecosystem.

Previous conceptions by Smilor, Gibson, and Kozmetsky (1989) and Smilor and Feeser (1991) foretold the typical image of an entrepreneurial ecosystem. The conversation of entrepreneurial ecosystems has principally focused on the vital constituents, whereas mostly overlooking the procedures or "recipes" for their grouping into a justifiable situation with entrepreneurial liveliness. The progressions are contingent on the procedures or links within an entrepreneurial ecosystem, which alter over the period (Spigel, 2017a; Stam, 2007). Significant dealings may also embrace movements to and from places outside the confined ecosystem. The crucial paradigm in an entrepreneurial ecosystem is that it is a scheme. "The universal circumstances are the core of the ecosystem: systems of businesspersons, headship, investment, talent, knowledge, and support services. The presence of these elements and the interaction between them predominantly determine the success of the ecosystem" (Stam, 2015, p. 1766).

The term "entrepreneurial ecosystem" was preceded by the "entrepreneurial system" in the work of Spilling (1996), subsequently taken up by Neck, Meyer, Cohen, and Corbett (2004). For Spilling (1996, p. 91), the "entrepreneurial system consists of complexity and diversity of actors, roles, and environmental factors that interact to determine the entrepreneurial performance of a region or locality." The system of entrepreneurial ecosystems and the interaction of their components and actors are critical: as a system changes over time, its elements change, and relationships among elements change. Entrepreneurial ecosystems are a means to create and maintain a dynamic local process of entrepreneurship as cumulative causation (or a virtuous circle; Feldman, Francis, \& Bercovitz, 2005; Malecki, 2009). In this regard, role models - positive regional entrepreneurial examples - are central (Bosma, Hessels, Schutjens, Van Praag, \& Verheul, 2014; Fornahl, 2003).

Role models, some of whom may be serial entrepreneurs or habitual founders, serve as examples of entrepreneurial success, offering advice and sometimes investment capital as angels or venture capitalists (Mason, 2008; Mason \& Harrison, 2006; Westhead \& Wright, 1999). The value (symbolic capital) accorded to mentorship is a key difference between regional cultures (Spigel, 2017b). A particular part of the development of strong ecosystems is that entrepreneurs who have succeeded with a blockbuster firm remain active in the local ecosystem, actively participating in it by reinvesting their profit and experience back into it either as investors or mentors. This is the "entrepreneurial recycling" evident in several studies (Bahrami \& Evans, 1995; Brown \& Mason, 2017; Ensign \& Farlow, 2016; Mason \& Harrison, 2006; Napier \& Hansen, 2011) and the "creative reassembly" seen in some ecosystems (Hwang \& Horowitt, 2012). The entrepreneurial ecosystem is a concept that is fundamentally spatial - and centrally local. Spinoffs or spinouts are especially likely from large anchor firms that act as seedbeds for nascent entrepreneurs (Mayer, 2013a).

Some entrepreneurial ecosystems support sector-specific sub-ecosystems, such as the "foodie" ecosystem in Boulder, Colorado (Strom, 2017), and the multiple spinoff families in Seattle (Mayer \& Armstrong, 2011). Bahrami and Evans (1995) were among the first to describe "a mutually supportive spiral of entrepreneurship and innovation" in the "Silicon Valley ecosystem," identifying the components and the key process of "flexible recycling" of old to new firms, funded by angels and supported by a sophisticated service infrastructure. Van de Ven (1993) focused on the infrastructure for entrepreneurship in the context of "an industrial infrastructure for entrepreneurship" and the "interorganizational community ... necessary to develop and commercialize a technological innovation" (p. 214). His inclusion of organizations beyond the entrepreneur evoke the ecosystem, but these organizations are not local; later, Van de Ven, Sapienza, and Villanueva (2007) included the local community as part of the "collective."

Despite these accepted trends, uncertainty still surrounds the sequence of events. Must venture capital already be in place for entrepreneurs to emerge? Feldman (2001) and 
Mason (2008) insist that venture capital and other supportive conditions follow rather than precede the emergence of entrepreneurial activity. By contrast, Mahroum (2016) finds venture capital as one of the few ecosystem conditions common to a set of 11 successful "black swan" start-ups from unlikely places. Mason and Brown (2014) suggest a more nuanced situation, citing a critical mass of seed and start-up investors to provide finance and hands-on support. Both cashed-out and current entrepreneurs and senior-level managers may become business angels. Angel networks and angel groups have emerged to formalize the (previously mostly informal) role of angels (Lerner \& Schoar, 2016; Mason, Botelho, \& Harrison, 2016). Seed capital funds and business accelerators are also important. The presence of venture capital funds is, arguably, not essential, since venture capital can be "imported" at first and then develop locally as angels and investors emerge from the local population of entrepreneurial successes, as the experience of San Diego suggests (Walshok \& Shragge, 2014). Finance, therefore, is another link from an entrepreneurial ecosystem to the outside - in this case, sources of finance and potential new markets.

\subsection{Economic Integration}

Integration defined as a process of "the grouping together of units or factors to form a single whole. Integrated development may, therefore, mean either the integration of several regions or increased cohesion between sectors, regions, and social classes" (Perroux, 2010). In this research, we focus on the integration of sectors between countries' transportation and digital technologies. The critical point in the discussion about international economic integration is the degree of state participation. Some argue that the market is the most effective regulator of the economy, and therefore see integration as a creation of a single economic space based on free foreign trade and monetary policies. Other economic schools were trying to find a compromise between market mechanisms and the role of the state in the coordination of economic policies. In this research, we believe that unless a national state exists, it is not possible to achieve integration without the participation of member states. Therefore, when the full integration of economic systems of member countries is not the aim, integration is achieved on the principles of the market mechanism with the coordinating role of the state.

Trade facilitation integration agreements involve two parts: a definition of the fundamental trade enablement ideologies and a set of detailed, obligatory, and enforceable trade facilitation measures (Wille \& Redden, 2007). Balassa (1966) differentiated five stages of economic integration: free trade zone, the customs union, single market, economic union, full economic integration. There are several degrees of integration, depending on the type of agreement made between the trading countries and the grade to which blockades between them are removed. Economic integration has both favorable (the access to new markets) and unfavorable (increased foreign competition) effects on the local companies' development (Nguyen \& Enderwick, 2016). However, foreign competition forces domestic firms to become more innovative, productive, and as a result, more competitive (Kyophilavong, Vanhnalat, \& Phonvisay, 2017).

Huin, Luong and Abhary (2003) suggest that the industrial SMEs integrate and internalize more quickly and reactively with the help of advanced technologies. The regional digital economy has the potential to expand further (Pitakdumrongkit, 2018). The implementation of cooperative policy between regional states may assist enterprises to grow internationally (Soesastro \& Basri, 2005). Research finds that China's Belt and Road Initiative (BRI) has provided Chinese firms with significant incentives to speed up the pace of internationalization having a positive formal institutional effect on the export performance of Chinese SME's firms that target the "Belt" countries (Li, Liu, \& Qian, 2019). Previous economic integration initiatives such as the European Union (E.U.) and the Association of Southeast Asian Nations (ASEAN) proved to simplify export and import procedures and expand the market for SME.

\subsection{Eurasian Economic Union}

Recent global economic and geopolitical trends lead to the need for reviewing the development strategy of Kazakhstan by evaluating regional integration processes in Eurasia. The process of Euro-Asian integration has begun following the establishment of the Commonwealth of Independent States (CIS) after the dismantling of the Soviet Union in 1991. The concept of the Eurasian Union was initially proposed by the President of the Republic of Kazakhstan, N.A. Nazarbayev, in 1994. The aim of this initiative was a voluntary, equitable integration, joint political and economic development of the post-Soviet economies, to take a leading position in the global economy (Dragneva \& Wolzsuk, 2012). That concept presented the principles, objectives, and mechanism of formation of the Eurasian Union, provided the establishment of several coordinating supranational structures, and sat out the basic directions of cooperation - the economy, a science, a culture, and education, and an environment. Participation in integration unions is the priority for Kazakhstan as the country sees excellent opportunities to develop capabilities based on regional integration. The main goal of integration is stability, economic development, and security in the region. Table 1 presents an evolution of economic integration within the Eurasian Economic Union.

Table 2 presents the geographic and economic characteristics of member countries. As it can be observed, Russia is the dominant member by area, market size, and national income. 
Table 1: Evolution of Eurasian Economic Union

\begin{tabular}{|l|l|l|l|l|}
\hline \multicolumn{1}{|c|}{ Union } & \multicolumn{1}{|c|}{ Period } & \multicolumn{1}{c|}{ Type } & \multicolumn{1}{c|}{ Main principles } & \multicolumn{1}{c|}{ Member countries } \\
\hline $\begin{array}{l}\text { Eurasian Economic } \\
\text { Community } \\
\text { EurAsEC) }\end{array}$ & $2000-2014$ & Free trade area & no trading barriers & $\begin{array}{l}\text { Belarus Kazakhstan } \\
\text { Kyrgyzstan } \\
\text { Russia } \\
\text { Tadjikistan }\end{array}$ \\
\hline $\begin{array}{l}\text { Eurasian Customs } \\
\text { Union (EACU) }\end{array}$ & 2010 & Custom union & $\begin{array}{l}\text { no customs, standard tariff on all } \\
\text { import goods }\end{array}$ & $\begin{array}{l}\text { Armenia, } \\
\text { Belarus, Kazakhstan, Russia }\end{array}$ \\
\hline $\begin{array}{l}\text { Eurasian Economic } \\
\text { Space (EES) }\end{array}$ & 2012 & Single market & $\begin{array}{l}\text { free movement of people, goods, } \\
\text { services, and capital }\end{array}$ & $\begin{array}{l}\text { Armenia, } \\
\text { Belarus, Kazakhstan, } \\
\text { Kyrgyzstan, } \\
\text { Russia }\end{array}$ \\
\hline $\begin{array}{l}\text { Eurasian Economic } \\
\text { Union (EAEU) }\end{array}$ & 2015 & Single market & $\begin{array}{l}\text { free movement of people, goods, } \\
\text { services, and capital, universal } \\
\text { macroeconomic policies, } \\
\text { transport, industry and agriculture, } \\
\text { competition and antitrust regulation }\end{array}$ & $\begin{array}{l}\text { Armenia, } \\
\text { Belarus, Kazakhstan, } \\
\text { Kyrgyzstan, } \\
\text { Russia }\end{array}$ \\
\hline
\end{tabular}

Table 2: Selected economic and geographic indicators of member countries (2017-2018)

\begin{tabular}{|l|c|c|c|c|c|}
\hline \multicolumn{1}{|c|}{ Country } & $\begin{array}{c}\text { Area } \\
\text { Tkm2 }\end{array}$ & $\begin{array}{c}\text { Population } \\
\text { In Millions }\end{array}$ & $\begin{array}{c}\text { Life expectancy at } \\
\text { birth, total (years) }\end{array}$ & \multicolumn{2}{c|}{ Adjusted net national income per capita } \\
\cline { 5 - 6 } & & & Current US\$ & Annual \% Growth \\
\hline Armenia & 30 & 2952 & 74,8 & 3412 & 9,1 \\
\hline Belarus & 208 & 9485 & 74,1 & 4980 & 3,4 \\
\hline Kazakhstan & 2725 & 18276 & 73,0 & 6378 & 0,9 \\
\hline Kyrgyzstan & 200 & 6316 & 71,2 & 971 & 7,1 \\
\hline Russia & 17125 & 144478 & 72,1 & 8519 & 2.0 \\
\hline Tajikistan & 142 & 9101 & 71,2 & 793 & - \\
\hline
\end{tabular}

Source: World bank

The Eurasian Economic Area was established in 2012 as a common market that provides free movement of persons, goods, services, and capital. The Eurasian Economic Space initially consisted of Belarus, Kazakhstan, and Russia, and was expanded when Armenia and Kyrgyzstan joined in 2015 (Tarr, 2016). The critical direction at this stage is the creation of a common market, in particular, the market of energy resources. The EAEU introduces the free movement of goods, capital, services, and people, and provides for standard policies in the macroeconomic sphere, transport, industry and agriculture, energy, foreign trade and investment, customs, technical regulation, competition, and antitrust regulation. The Eurasian Economic Union is designed to achieve several objectives such as improve resource allocation, efficiency in production, competition, reduce the price for consumers and expand consumer choice, increase investment by firms that want to take advantage of the broader market size.

\section{Research Methodology}

The methodology for this research was a survey of companies (Ritchie \& Spencer, 2002). A group of companies operating in Kazakhstan was selected to determine the effect of EAEU on their activity. The survey questionnaire was administered to 204 large-, small-, and medium-sized firms from different sectors of the economy in Kazakhstan. Out of the 204 companies, only ten percent of the sample were large-scale industries, as the researchers intended to offer a comprehensive study with all types of industries. Only 184 fully completed answers were received. The response rate was $90 \%$. The questionnaire aimed to explore whether SMEs in Kazakhstan feel the effect of integration in EAEU. Closed-end types of questions were used for the questionnaire. Respondents could choose among available answers to help find an association (positive, negative, 
neutral) between economic integration and company activity. To assess companies' sensitivity towards Eurasian economic integration, we asked the executives whether integration had an impact on their respective businesses. They were asked whether this impact was positive or negative.

Positive effects included companies' intentions for regional expansion, increasing sales, and whether they are acting to increase their affordability to take advantage of integration. Examples of the questions are: "Are there suppliers from the following countries among your partner companies?" "Are there buyers from the following countries among your partner companies?", "If exporting abroad, indicate which country", "New markets have opened for you in the following countries: (list of countries)." The companies in our study encompass a wide range of industries, including energy, industrial goods, construction, financial services, catering, retail, I.T., and telecommunications. Following the classical view of the three-sector theory developed by Fisher (1939), we distributed respondents into three sectors of activity: extraction of raw materials (primary), manufacturing (secondary), and services (tertiary). The primary sector includes the extraction of raw materials, mining, and agriculture.

The secondary sector is concerned with the manufacturing of final goods. The tertiary sector is concerned with offering services like trade, I.T., logistics, telecommunication, retail, tourism, banking, and entertainment. The focus of the research was small- and medium-sized organizations. According to the Law of the Republic of Kazakhstan, "About private entrepreneurship," Kazakhstani law defines a small business as one with no more than 50 employees. A medium-sized business is a company with between 51 and 250 employees. Large companies are well-defined as distinct legal entities carrying out the entrepreneurial activity with more than 250 employees. Many of the companies in this research are small enterprises $-65 \%$ of respondent companies, $25 \%$ medium enterprises, and $10 \%$ large enterprises representing all three sectors of the economy.

\section{Results}

Although the integration process in the post-Soviet space has a long history, the Eurasian Economic Union is a relatively young institution. Thus, it may be too early to expect the effects of integration on the entrepreneurial ecosystem. However, some trends could be identified. To suggest a further direction, this research provided the following results. The share of total trade among Kazakhstan and EAEU member countries has increased since 2015, which shows that countries are using the opportunities provided by integration and non-tariff trade for their benefit. Most of the respondent companies state that they have not noticed any effect of integration on their business activity, with $39 \%$ of executives disclosing positive or negative effects of economic integration. Most companies from the tertiary sector did not experience any effect of Eurasian Economic Union on their businesses; most of them are small enterprises $(84.3 \%)$ that mostly provide services. The small scale of their activity can explain this. Medium-sized businesses are the most sensitive to the integration effects among the companies we surveyed; $48,6 \%$ of companies responded that there was an impact on their business in the aftermath of joining the Eurasian Economic Union. These findings show that more research needs to be conducted to understand how entrepreneurial ecosystems function and what institutions can be developed to support SMEs in emerging countries. Despite their importance for the economy, entrepreneurial ecosystems are a relatively new topic in the literature on international business (Autio, Nambisan, Thomas \& Wright, 2018; Brown \& Mason, 2017). As ecosystems can be geographical and online, it is especially interesting how regional integration and digital technologies can support the development of SMEs. The directions of further research concerning the possible diversification in Kazakhstan could address the following questions: how are digital entrepreneurial ecosystems developing in emerging countries context? What is the role of regional integration in fostering entrepreneurial ecosystems? What kind of government policies help or hinder entrepreneurial ecosystems?

The survey asked people to indicate at which level their businesses operate: regional, national, and international levels. The most significant area where companies operate is the regional level $(51,8 \%)$. The research also attempted to garner information from the countries in which respondents' companies export. They were offered the choice of six options: Bangladesh Republic, China, Georgia, Russia, Commonwealth of the Independent States, and Uzbekistan. Almost two-fifths of respondents export their goods and services in Russia $(41,7 \%)$. The second most popular importer country is China, with $25 \%$.

In this study, respondents were asked whether new sales markets were opened in the following countries, such as Russia, Kyrgyzstan, Belarus, and Armenia. Also, they were offered another option that suggests there are other states apart from proposed ones. As per the opinions of respondents, the majority of companies indicated that new sales markets opened in Russia (44.2\%) and Kyrgyzstan $(20.9 \%)$ It should be noted that such sectors as trade $(9.73 \%)$ and services (7\%) in Russia and trade (4.42\%) and services $(3.53 \%)$ in Kyrgyzstan dominate new markets. Meanwhile, we learned at what level the company should operate in order to discover a new sales market from economic integration in Russia and Kyrgyzstan. Many companies that operate at the regional level have opened a new market in Russia (15\%), Kyrgyzstan (8\%) and Belarus (8.8\%). It indicates that the enterprise does not need to be a company that trades its goods 
or services internationally. As we see in our case, regional companies have discovered new opportunities through integration. The research reveals information about the opinions of entrepreneurs about which countries it becomes easier to buy from. There are six options: correct, partially correct, partially wrong, wrong, and there is no effect. The most significant group of respondents said that it is correct $(15 \%)$ or partially correct $(10 \%)$ that now it is now easier to buy mostly from Russia and Belarus. Also, a significant part of respondents state that it does not become easier (wrong $-8,9 \%)$ to buy from Armenia, or there is no effect $(45,6 \%)$.

The research also highlighted information about the number of business partners after economic integration; partnerships increased mainly from Russia and Kyrgyzstan, but no effects in getting partners after integration in Armenia and other countries. Companies active in trade (22.8\%) and construction $(12.2 \%)$ industries saw no effects in an increased number of new partners from Armenia, and those who are engaged in the trade (9.7\%) and services (11.4\%) have not found new partners from other countries. Another interesting question was whether it was easy for new companies that operated in the market from 1-3 years to find new partners in the market: this was achieved only by successful companies. The research shows that companies that have been operating on the market for 15-20 years (as much as 14\%) and 5-10 years (10\%) have quickly found new partners from Russia. The research has several variables, such as different countries and options that reflect their opinion. Respondents had to answer the question from which countries competition increased after integration and to what degree. The majority replied that competition increased from Russia. They answered "correct" and "partially correct."

On the contrary, fewer respondents claimed that the competition did not increase from Armenia. The information provides us with the fact that $2 \%$ of the total responses chose this option. It is also notable that a considerable number of people answered that there is no effect of increased competition from other countries apart from states proposed in the survey. Almost one in ten respondents mentioned this option $(10,4 \%)$. The outcomes of the questionnaire disclosed that in global competition, integration does not play a significant role, except from Russia (16.7\%) and Belarus (8.33\%). We calculated that only Almaty (5.6\%) faced competition from Russia in such sectors as trade $(5 \%)$ and services $(5 \%)$. Concurrently, a significant portion of people answered that competition from Russia does not interfere with their businesses.

Moreover, economic integration has brought more partners and opened new opportunities for companies, and compared with that, Kazakhstan has a minimal number of competitors. The question was, "What consequences do you expect from economic integration for the economy of
Kazakhstan, large companies, small and medium enterprises, your industry, and your company?" Respondents had to choose among several options: positive, partially positive, none, partially negative, and negative. Most people indicated that economic integration brings positive consequences, especially to the economy of Kazakhstan and big companies (corresponding with 29,3\% and 21,9\% from total "positive" responses). Only a small number of respondents thought that integration had partially negative or negative consequences on the economy of Kazakhstan. The study survey asked entrepreneurs their level of knowledge about the Eurasian Economic Union (EAEC) between Kazakhstan, Russia, Belarus, Kyrgyzstan, Armenia (information on norms, standards and customs tariffs). They were offered four choices: have detailed, sufficient, little, or do not have any knowledge. According to the research outcome, more than half $(55 \%)$ answered that they do not have any knowledge, while only $0,9 \%$ replied that they have little knowledge about these issues. Some $44,1 \%$ of respondents indicated they "have sufficient expertise". This article provides the latest point of view on the entrepreneurial ecosystem's influence on economic integration to the policymakers of Kazakhstan. Think-tanks on the Kazakh economy can benefit from our research by adding expertise about how to manage network effects while planning investment projects, as well as with transactions, modes, and fixed nodes, acquisition, and greenfield investments.

\section{Conclusion and Future Research}

The perceptions of entrepreneurial ecosystems and economic integration, in general, and in Russian CIS countries, in particular, attract scholarly curiosity. The paper presented first-hand information about the influence of an ecosystem on the economic integration at regional, national, and international level among diverse industrial sectors of Kazakhstan. Besides, the paper posits certain areas of influence on the industrial sectors that will provide knowledge to the country's policymakers to achieve network effects while scheduling investment projects and greenfield ventures. The result of this research will support policymakers and entrepreneurs at all levels to work on beneficial paths that will improve networks, chiefly as it relates to access to capital and markets, which represents the principal problems of entrepreneurship.

There is wide scope for similar kinds of industry-wide and sector-wide research with a significant number of subjects. The researchers invite further empirical research to know the impact of the entrepreneurial ecosystem on Kazakhstan's competitive advantage along with the Russian Commonwealth of Independent States (CIS) countries within a network theory perspective. 


\section{References}

Acs, Z. J., Stam, E., Audretsch, D. B., \& O'Connor, A. (2017). The lineages of the entrepreneurial ecosystem approach. Small Business Economics, 49, 1-10.

Audretsch, D. B., Bozeman, B., Combs, K. L., Feldman, M., Link, A. N., Siegel, D. S., \& Wessner, C. (2002). The economics of science and technology. The Journal of Technology Transfer, 27(2), 155-203.

Autio, E., Nambisan, S., Thomas, L. D., \& Wright, M. (2018). Digital affordances, spatial affordances, and the genesis of entrepreneurial ecosystems. Strategic Entrepreneurship Journal, 12(1), 72-95.

Bahrami, H., \& Evans, S. (1995). Flexible re-cycling and hightechnology entrepreneurship. California Management Review, $37(3), 62-89$.

Balassa, B. (1966). Towards a theory of economic integration. Kyklos, 14(1), 1-17.

Beeche, M. (2015). Can Sydney become the startup city that ecosystem stakeholders want it to be? Startup Daily. Retrieved August 14, 2019 from: https://www.startupdaily.net/2015/08/ can-sydney-become-startup-city-ecosystem-stakeholderswant/

Brown, R., \& Mason, C. (2017). Looking inside the spiky bits: a critical review and conceptualization of entrepreneurial ecosystems. Small Business Economics, 49(1), 11-30.

Bosma, N. S., Stam, E., \& Wennekers, S. (2012). Entrepreneurial employee activity: A large scale international study. Discussion Paper Series 12(12). Netherlands: Tjalling C. Koopmans Research Institute.

Bosma, N., Hessels, J., Schutjens, V., Van Praag, M., \& Verheul, I. (2014). Entrepreneurship and role models. Journal of Economic Psychology, 33, 410-424.

Business Dictionary (2019). Entrepreneurship. RetrievedDecember 10, 2019 from: http://www.businessdictionary.com/definition/ entrepreneurship.html

Clifford, C. (2013). Why everyone will have to become an entrepreneur. Retrieved December 15, 2019, from: https:// www.entrepreneur.com/article/228176.

Cooke, P. (2007). Regional innovation, entrepreneurship, and talent systems. The International Journal of Entrepreneurship and Innovation, 7, 117-139.

Custer, J. (2013). Four key lessons for cultivating entrepreneurship. CIPE Development Blog, April 10.

Darden School of Business. (2012). Policy playbook. Charlottesville, VA: Darden School of Business, University of Virginia.

Decker, R. A., Haltiwanger, J., Jarmin, R. S., \& Miranda, J. (2016). Where has all the skewness gone? The decline in high-growth (young) firms in the U.S. European Economic Review, 86, 4-23.

Dragneva, R., \& Wolczuk, K. (2012). Russia, the Eurasian Customs Union, and the E.U.: Cooperation, stagnation, or rivalry? Chatham House Briefing Paper REP BP 2012/01.
Available at: https://www.chathamhouse.org/sites/default/ files/public/Research/Russia\%20and\%20Eurasia/0812bp_ dragnevawolczuk.pdf

Ensign, P. C., \& Farlow, S. (2016). Serial entrepreneurs in the Waterloo ecosystem. Journal of Innovation and Entrepreneurship, 5, 20. https://doi.org/10.1186/s13731-0160051-y

Erina, I., Shatrevich, V., \& Gaile-Sarkane, E. (2017). Impact of stakeholder groups on the development of a regional entrepreneurial ecosystem. European Planning Studies, 25, 755-771.

Feldman, M. P. (2001). The entrepreneurial event revisited: Firm formation in a regional context. Industrial and Corporate Change, 10, 861-891.

Feldman, M. P. (2014). The character of innovative places: entrepreneurial strategy, economic development, and prosperity. Small Business Economics, 43(1), 9-20.

Feldman, M. P., Francis, J., \& Bercovitz, J. (2005). Creating a cluster while building a firm: Entrepreneurs and the formation of industrial clusters. Regional Studies, 39, 129-141.

Fisher, A.G. (1939). Production, primary, secondary, and tertiary. Economic Record, 15(1), 24-38.

Fornahl, D. (2003). Entrepreneurial activities in a regional context. In: D. Fornahl, \& T. Brenner (Eds.), Cooperation, networks, and institutions in regional innovation systems (pp. 38-57). Cheltenham, England: Edward Elgar.

Gaddefors, J., \& Anderson, A. R. (2017). Entrepreneursheep and context: when entrepreneurship is greater than entrepreneurs. International Journal of Entrepreneurial Behavior \& Research, 23(2), 267-278.

Gomes, L.A.V., Facin, A.L.F., Salerno, M.S., \& Ikenami, R.K. (2016). Unpacking the innovation ecosystem construct: Evolution, gaps, and trends. Technological Forecasting and Social Change, 136, 30-48. https://doi.org/10.1016/j. techfore.2016.11.009.

Isenberg, D. (2011). The entrepreneurship ecosystem strategy as a new paradigm for economic policy: Principles for cultivating entrepreneurship. Presentation at the Institute of International and European Affairs, Dublin, Ireland, May 12.

Hekkert, M. M. P., Suurs, R. A. A., Negro, S. O., Kuhlmann, S., \& Smits, R. E. H. M. (2007). Functions of innovation systems: A new approach for analyzing technological change. Technological Forecasting and Social Change, 74, 413-432.

Huin, S. F., Luong, L. H. S., \& Abhary, K. (2003). Knowledgebased tool for planning of enterprise resources in ASEAN SMEs. Robotics and Computer-Integrated Manufacturing, 19(5), 409-414.

Hwang, V. W., \& Horowitt, G. (2012). The rainforest: The secret to building the next Silicon Valley. Los Altos Hills, CA: Regenwald.

Julien, P.A. (2007). A theory of local entrepreneurship in the knowledge economy. Cheltenham, UK: Edward Elgar. 
Jumasseitova, A., \& M. Bigabatova. (2017). Eurasian economic integration: the challenges for small and medium companies. Central Asian Economic Review 119(1), 110-121.

Kopeikina, L. (2008). Ecosystem for Innovation Business. Angel Investor \& Venture Capital, 1(7). [Russian].

Kyophilavong, P., Vanhnalat, B., \& Phonvisay, A. (2017). Lao SME participation in regional economic integration. Journal of Southeast Asian Economies, 34(1), 193-220.

Li, J., Liu, B., \& Qian, G. (2019). The belt and road initiative, cultural friction, and ethnicity: Their effects on the export performance of SMEs in China. Journal of World Business, 54(4), 350-359.

Lerner, J., \& Schoar, A. (2016). Rise of the angel investor: A challenge to public policy. Washington, DC: Third Way.

Mack, E. A., \& Qian, H. (Eds.) (2016). Geographies of entrepreneurship. Abingdon, UK: Routledge.

Mahroum, S. (2016). Black swan start-ups: Understanding the rise of successful technology business in unlikely places. London, UK: Palgrave Macmillan.

Malecki, E. J. (2009). Geographical environments for entrepreneurship. International Journal of Entrepreneurship and Small Business, 7, 175-190.

Mason, C. (2008). Entrepreneurial dynamics and the origin and growth of high-tech clusters. In: C. Karlsson (Ed.), Handbook of research on innovation and clusters (pp. 33-53). Cheltenham, UK: Edward Elgar.

Mason, C., Botelho, T., \& Harrison, R. (2016). The transformation of the business angel market: Empirical evidence and research implications. Venture Capital, 18, 321-344.

Mason, C. M., \& Harrison, R. T. (2006). After the exit: Acquisitions, entrepreneurial recycling, and regional economic development. Regional Studies, 40, 55-73.

Mason, C., \& Brown, R. (2014). Entrepreneurial ecosystems and growth-oriented entrepreneurship. Paris, France: OECD.

Mayer, H. (2013a). Firm building and entrepreneurship in secondtier high-tech regions. European Planning Studies, 21, 13921417.

Mayer, H., \& Armstrong, S. (2011). Featured graphic: The visual genealogy of spinoff companies in the technology sector in Seattle, 2008. Environment and Planning A, 43, 763-764.

Moore, J. F. (1993). Predators and prey: A new ecology of competition. Harvard Business Review, 71(3), 75-86.

Napier, G., \& Hansen, G. (2011). Ecosystems for young scalable firms. Copenhagen, Denmark: FORA.

National Venture Capital Association. (2020). Venture Investment - Regional Aggregate Data. Retrieved May 13, 2020, from: https://web.archive.org/web/20160408104240/http://nvca.org/ research/venture-investment/

Neck, H. M., Meyer, G. D., Cohen, B., \& Corbett, A. C. (2004). An entrepreneurial system view of new venture creation. Entrepreneurship Theory and Practice, 42, 190-208.
Nguyen, H. T. N., \& Enderwick, P. (2016). The perceptions and responses of Vietnamese firms towards deeper regional economic integration: case studies from the food processing industry. Journal of Southeast Asian Economies, 33(1), 65-82.

Perroux, F. (2010). A new concept of development: basic tenets. Abingdon, UK: Routledge.

Pitakdumrongkit, K. (2018). Addressing Digital Protectionism in ASEAN: Towards better regional governance in the digital age. Nanyang Technological University, Singapore. Available at: https://www.rsis.edu.sg/wp-content/uploads/2018/03/ PR180426_Addressing-Digital-Protectionism-in-ASEAN.pdf

Rajan, R.G., \& Zingales, L. (1998). Financial dependence and growth. American Economic Review, 88(3), 559-586.

Ritchie, J., \& Spencer, L. (2002). Qualitative data analysis for applied policy research. In: Bryman, A. \& Burgess, R.G. (Eds.), Analyzing qualitative data (pp. 187-208). New York, NY: Routledge.

Scott, S., \& Venkatraman, S. (2000). The promise of entrepreneurship as a field of research. Academy of Management Review, 25, 217-226.

Smilor, R. W., \& Feeser, H. R. (1991). Chaos and the entrepreneurial process: Patterns and policy implications for technology entrepreneurship. Journal of Business Venturing, 6, 165-172.

Smilor, R. W., Gibson, D. V., \& Kozmetsky, G. (1989). Creating the technopolis: High-technology development in Austin, Texas. Journal of Business Venturing, 4, 49-67.

Soesastro, H., \& Basri, M. C. (2005). The political economy of trade policy in Indonesia. ASEAN Economic Bulletin, 22(1), 3-18.

Spigel, B. (2017a). The relational organization of entrepreneurial ecosystems. Entrepreneurship Theory and Practice, 41, 49-72.

Spigel, B. (2017b). Bourdieu, culture, and the economic geography of practice: Entrepreneurial mentorship in Ottawa and Waterloo, Canada. Journal of Economic Geography, 17, 287-310.

Spilling, O. R. (1996). The entrepreneurial system: On entrepreneurship in the context of a mega-event. Journal of Business Research, 36, 91-103.

Stam, E. (2007). Why butterflies don't leave: Locational behavior of entrepreneurial firms. Economic Geography, 83, 27-50.

Stam, E. (2013). Knowledge and entrepreneurial employees: A country-level analysis. Small Business Economics, 41(4), 887-898.

Stam, E., \& Spigel, B. (2017). Entrepreneurial Ecosystems. In: Blackburn, R., De Clercq, D., Heinonen, J. \& Wang, Z. (Eds). Handbook for Entrepreneurship and Small Business. London, UK: Sage Publications.

Stam, E. (2015). Entrepreneurial ecosystems and regional policy: A sympathetic critique. European Planning Studies, 23, 17591769.

Strom, S. (2017). Foodies Know: Boulder Has Become a Hub for New Producers. The New York Times, February 4, B1. Retrieved 
April 10, 2020 from: https://www.nytimes.com/2017/02/04/ business/foodies-know-boulder-has-become-a-hub-for-newproducers.html

Tarr, D. G. (2016). The Eurasian Economic Union of Russia, Belarus, Kazakhstan, Armenia, and the Kyrgyz Republic: Can It Succeed Where Its Predecessor Failed? Eastern European Economics, 54 (1), 1-22.

The Entrepreneurship Handbook. (2019). What is Entrepreneurship? Retrieved December 15, 2019, from: https:// entrepreneurhandbook.co.uk/entrepreneurship/

Van de Ven, A. H. (1993). The development of an infrastructure for entrepreneurship. Journal of Business Venturing, 8, 211-230.

Van de Ven, A. H., Sapienza, H. J., \& Villanueva, J. (2007). Entrepreneurial pursuits of self-and collective interests. Strategic Entrepreneurship Journal, 1, 353-370.
Westhead, P., \& Wright, M. (1999). Contributions of novice, portfolio, and serial founders located in rural and urban areas. Regional Studies, 33, 157-173.

Wille, P., \& Redden, J. (2007). A comparative analysis of trade facilitation in selected regional and bilateral trade agreements and initiatives. Trade Facilitation Beyond the Multilateral Trade Negotiations: Regional Practices, Customs Valuation, and Other Emerging Issues, 27.

World Economic Forum. (2013). Entrepreneurial ecosystems around the globe and company growth dynamics: Industry agenda. Geneva, Switzerland: World Economic Forum.

Ylinenpää, H. (2009). Entrepreneurship and innovation systems: Towards the development of the ERIS/IRIS concept. European Planning Studies, 17, 1153-1170. 